\title{
Jewish and Christian Approaches to Suffering in the Reception of Psalm 137
}

\author{
SUSAN GILLINGHAM (UNIVERSITY OF OXFORD)
}

\begin{abstract}
This paper illustrates how Psalm 137 is used to address the question of suffering by Jews and Christians during various crises of faith. In Jewish tradition, the psalm has a "meta-narrative" which meant reading it as a story set in poetry, speaking to the people as a whole not only emotionally but also materially. Only in later Christian reception does the engagement with this psalm become more obviously physical; Christians tend to avoid seeing the psalm as a meta-narrative and instead select single verses or phrases from it in order to teach spiritual lessons, often through the use of "allegory", where different words are used to speak to more individual concerns. A selective survey of Jewish and Christian approaches to suffering in the reception of Psalm 137 suggests that the Christian reception of Psalm 137 in times of suffering is distinct from the Jewish one. Whereas early Jewish readings had a more corporate and physical emphasis, as crisis after crisis threatened the identity of the Jews as a people, early Christian readings are more personal and spiritualised, heightened through the use of allegory.

KEYWORDS: allegory, Christian exegetical tradition, crises of faith, exile, Jewish exegetical tradition, Psalm 137, meta-narrative, reception, suffering.
\end{abstract}

\section{A INTRODUCTION}

I have presented two papers on Psalm 137 to colleagues in the Department of Old Testament Studies at the University of Pretoria, where I am proud to be a Research Associate. The first was actually at Worcester College, University of Oxford, in 2010, when I hosted a conference entitled "Jewish and Christian Approaches to the Psalms," and where Professor Dirk Human gave a paper. The proceedings were published in 2013 and some of the material in this paper comes from my research for that publication. ${ }^{1}$ The second paper was a year later, when

* Article Submitted: 2019/03/04; peer reviewed: 2019/05/20; accepted: 2019/07/16. Susan Gillingham, "Jewish and Christian Approaches to Suffering in the Reception of Psalm 137,” OTE 32 no. 2 (2019): 444-463. DOI: https://doi.org/10.17159/2312-3621 /2019/v32n2a11.

1 For a more comprehensive account of the reception history of Ps 137, see Susan E. Gillingham, "The Reception of Psalm 137 in Jewish and Christian Traditions," in Jewish and Christian Approaches to the Psalms: Conflict and Convergence (ed. Susan E. Gillingham; Oxford: Oxford University Press, 2013), 64-82. I am most grateful to the editors of OUP for allowing parts of that paper to be reproduced here. 
I spoke at Project Psalms as part of the OTSSA Annual Conference on Psalms, and this was at the University of Pretoria. That paper was entitled "Jewish and Christian Approaches to Suffering in the Reception of Psalm 137," and it has never been published. Professor Dr Phil Botha also participated in this event. Now, some seven years later, with imminent retirement looming for both of us, it seemed appropriate to revisit that paper and offer it as a sign of my respect for Phil Botha's work: We have met several times since 2011 at international conferences where we have both given papers, and I have always gained a good deal from Phil's studies of individual psalms. We also share the same interests in the wisdom psalms and in the shaping of the Psalter as a whole. I know Phil is also cautiously drawn to reception history studies of the Psalms, and so this paper is to persuade him to move post-retirement a little further in that direction himself.

In this paper I intend to show how Psalm 137 is used to address the question of suffering by Jews and Christians during various crises of faith. I am aware that another colleague, Professor Bob Becking, Senior Research Professor at the University of Utrecht, has argued in a paper (also given at the University of Pretoria) that the exiles might not have encountered terrible material suffering in Babylon, and that Psalm 137 speaks more about the psychological trauma as about anything more material. ${ }^{2}$ Although I agree that there is archaeological evidence that supports this, I would argue nevertheless that the later reception of Psalm 137 in Jewish tradition has undoubtedly addressed both aspects of suffering. The psalm has a "meta-narrative" whose poetic story speaks not only emotionally but also materially, and this is addressed to the people as a whole. Only in later Christian reception does the engagement with this psalm become more obviously physical and literal; Christians tend to avoid seeing the psalm as a meta-narrative and instead select single verses or phrases from it in order to teach spiritual lessons, often through the use of "allegory," where different words (rather than the psalm as a whole) are used to speak to more individual concerns. In what follows I offer a study of Jewish and Christian reception history of Psalm 137 to demonstrate these very different concerns.

\section{B JEWISH APPROACHES TO SUFFERING THROUGH THE CREATION OF A "META-NARRATIVE"}

\section{$1 \quad$ Psalm 137 in the exilic and post-exilic periods}

Many Jews would read this psalm as having been composed during the Babylonian exile. Often Jeremiah, the "weeping prophet," has been seen as the author: indeed, later Greek versions sometimes even included the

2 See Bob Becking, "Does Exile Equal Suffering? A Fresh Look at Psalm 137," in Exile and Suffering: A Selection of Papers read at the 50th Anniversary Meeting of the Old Testament Society of South Africa, Pretoria August 2007 (OTS 50; ed. Bob Becking and Dirk J. Human; Leiden: Brill, 2009), 183-202. 
title tw/ Ieremia. So the curse over the Edomites in v. 7 is read in the light of Jer 49:8-22, and the curse over the Babylonians in vv. 8-9, in the light of Jer 51:164. ${ }^{3}$ But was Jeremiah ever in exile in Babylon? One answer is to assume the date is in the early part of the exile, after the prophet had accompanied the first group of exiles as far as the Babylonian border, upon which he returned to Judah. Another answer is to suggest it was after his return from Egypt, once back in Judah. ${ }^{4}$

A more likely reading is to see Ps 137 as a composition after the exile, in Yehud, some time after 538 BCE. This reading was popular among the rabbis who argued that the psalm was composed and sung by Levitical singers, when once again songs of Zion could indeed be sung. Hence the word "there" (שָׁם) in vv. 1 and 3 is a time of looking back to Babylon - from Yehud. ${ }^{5}$ The fact the psalmist never prays for the restoration of Jerusalem but only for the downfall of Babylon does suggest a time after 538, when Jerusalem was being rebuilt, but before Darius completely destroyed the city of Babylon.

Nevertheless, in both readings Psalm 137 is seen to be about the Babylonian exile; it suggests an earthly drama in three parts. First, it tells the story of the community's suffering (vv. 1-4, noting the use of the first person plural throughout); secondly, the self-imprecation about never forgetting Jerusalem (vv. 5-6, noting here the use of the first person singular) is for anyone who cares passionately about Zion; and finally, the imprecation against the people's enemies (vv. 7-9 is mainly in the third person plural) applies literally to the Edomites and the Babylonians. The motif "remember!" found in each of the three parts (vv. 1, 6, 7) is what holds the psalm together as a whole.

\section{$2 \quad$ Psalm 137 in the second century BCE under Hellenistic rule}

After the time of Alexander the Great, and especially during the $2^{\text {nd }} \mathrm{BCE}$ at the time persecution under Antiochus Epiphanes, with his austere programme of Hellenization, many Jews began to feel that the exile had never actually ended. ${ }^{6}$ At this time Ps 137 would be particularly pertinent, with its focus on the suffering community in vv. 1-4, on Jerusalem as one's "highest joy" in vv. 5-6, and the vitriol against pagan nations in vv. 7-9. The main difference was that the

$3 \sqrt{ } \sqrt{ }$ נפhich is in Ps 137:9 occurs some nine times throughout Jeremiah, which may suggest further associations.

4 A problem here is the prophet's great age: hence another tradition arose that after an enforced exile in Babylon, Nebuchadnezzar, in his thirty-third year, invaded Egypt and held the prophet hostage in Babylon. See Josephus in Jewish Antiquities 10:18082, noted by James L. Kugel in his discussion of Ps 137; cf. James L. Kugel, In Potiphar's House: The Interpretive Life of Biblical Times (Cambridge, MA: Harvard University Press, 1990), 178-179.

5 שָָם can denote present experience as well: see, for example, Pss 48:6 (7) and 76:3 (4).

6 See for example Dan 9:20-7; 11:1-45. 
"Edomites" and "Babylonians" would have now been read as the Hellenizers those who had placed that "abomination of desolation" within the Temple and so re-created that sense of being unable to worship in a "foreign land".

\section{$3 \quad$ Psalm 137 after 70 CE under Roman rule}

The various versions of Paraleipomena of Jeremiah are usually dated between 70 and 135 CE. It is during this time that a different "meta-narrative" emerges. Now, in the context of the fall of Jerusalem in 70 CE and the Roman wars between 132-135, the psalm was understood, perhaps surprisingly, as from David, prophesying the future suffering of the Jews. Hence David "foresees" not only the fall of Jerusalem between 597-587 BCE in the first part of the psalm (vv. 1-4, 5-6) but also the fall of Jerusalem in $70 \mathrm{CE}$ and the final Diaspora in $135 \mathrm{CE}$ in the second part of the psalm (vv. 7-9). In this reading both Babylon and Edom became synonyms for Rome - not least because at this time it was deemed that Titus and the Roman Empire were of Edomite origin. ${ }^{7}$

\section{$4 \quad$ Psalm 137 by the sixth century CE}

By the time of the completion of Targum Psalms in about the $6^{\text {th }}$ CE, another layer of interpretation begins to emerge. Targum Psalms has several additional references. One concerns the Edomites in v. 7 ("who laid waste Jerusalem" [דאחריבו ירושלם דאמרין]) and suggests a double connotation - it refers not only to the Edomites, but also to the Romans. Another addition, in v. 6, concerning "the memory of Jerusalem" (דכרן ירושלם) alludes to the fact that, since $70 \mathrm{CE}$, the Temple no longer stands. The expansion in v. 3 to some of the songs "you used to utter" in Zion (שירתא דהויתון אמרין) again has a double reference, as after $70 \mathrm{CE}$ the songs of Zion were again silent. The reference to the Babylonians and the extent of their gloating and the people's distress in v. 3 ("because of their joy were saying..." [ובזוזנא על עסיק חדוא]) looks back not only to the Babylonian captivity but to Roman rule as well. In v. 4, the allusion to the psalmist as a Levite (i.e. not David, nor Jeremiah, nor Baruch) and the reference to the Levites maiming themselves to disqualify them from any enforced blasphemy in singing about Zion in an alien land (מניד קטעו ליועי אליוניהון בככיהון ואמרין) serves as a didactic tool to a community oppressed by the Gentiles: it warns all those (in their ongoing exile) not to capitulate to Gentile demands in any way. ${ }^{8}$ The addition in v. 5, "the voice of the holy spirit replied and says" ( מתיבא קל רוחא (דקודשא offers assurance directly from God to those who have been loyal in

\footnotetext{
7 There is a clear reference to this in the Babylonian Talmud, Gittin 57b. See Kugel, In Potiphar's House, 174-175.

8 The tradition of the self-mutilation of the Levites is also found in Pesikta Rabbati 136a, so it is not unique to Targum. It also occurs in Midrash Tehillim 137:5. See Timothy Edwards, Exegesis in the Targum of Psalms: The Old, the New and the Rewritten (Gorgias Dissertations 28: Biblical Studies 1; Piscataway, NJ: Gorgias, 2007), 108-111.
} 
suffering. The speakers of the curses in vv. 7 and 8-9 are "Michael prince of Jerusalem" (אמר מיכאל רבה דירושלם אידכר) and "Gabriel prince of Zion" (רמר ) גבריאל רבה דציון : this raises this cry of vengeance to a supernatural level, implying that the curse on the enemy comes not only from the people but from angelic beings as well.

The "meta-narrative" of Targum transforms Ps 137 into a drama of several speakers so that the action does not take place solely on earth but in heaven as well. At the beginning of the psalm it starts with the suffering community on earth, but by the middle of the psalm the scene has moved up to heaven (by way of the reference to the Holy Spirit) where it is God, not the psalmist, who vows loyalty to the memory of Jerusalem. This heavenly perspective continues in vv. 7-9 where it is the angelic protectorates of the nation, not the people, who cry out in vengeance against their enemies. ${ }^{9}$

\section{$5 \quad$ Psalm 137 in the Middle Ages}

Midrash Tehillim, whose final date is approximately some seven hundred years after Targum Psalms, clearly emphasises that Ps 137 is about the physical sufferings of the people from their first exile of 587 and onwards. Here the sufferings are even more intensified. For example, the use of "there" (שָָָם) in vv. 1 and 3 is used to heighten the fact that the Jews were allowed no rest-stop until they arrived in Babylon. ${ }^{10}$ The reference to the weeping by (עָל) the Babylonian waters (v. 1) is on account of (עַ) the people and their children actually being poisoned by the waters of the river Euphrates. The use of "also" (a) in v. 1 is an indication that the pain was so great that God Himself wept with them too. ${ }^{11}$ The hanging up of the harps on trees, as an act of defiance in refusing to comply with the captors' demands, was in order to prevent them being contaminated by foreign ground. ${ }^{12}$ It seems that this interpretation, building upon the tradition that Jeremiah was the author of the psalm, has been influenced by 4 Baruch and especially by the Paraleipomena of Jeremiah, which explains how and why a

9 See Moshe J. Bernstein, "Translation Technique in the Targum to Psalms. Two Test Cases: Psalms 2 and 137," in Society of Biblical Literature 1994 Seminar Papers: 130th Annual Meeting November 19-22, 1994, the Chicago Hilton and Towers Chicago, Il. (SBLSP 33; ed. Eugene L. Lovering; Atlanta, GA: Scholars, 1994), 326345, especially 338-43; also David Stec, The Targum of Psalms (ArBib 16; Collegeville, MN: Liturgical, 2005), 231.

10 Midrash Tehillim 137:1 and Pesiqta Rabbati 130b also refer to this. See Kugel, In Potiphar's House, 180-182, showing how Lam 4:19 and 5:5 were understood as Midrashim on this verse.

11 See Midrash Tehillim 137:1 and Pesiqta Rabbati 131b referred to in Kugel, In Potiphar's House, 181-184.

12 See Midrash Tehillim 137:3 and Pesiqta Rabbati 144a and 144b, referred to in Kugel, In Potiphar's House, 185-89 and Note 35. 
letter from Jeremiah highlighted the people's grief which in turn gave rise to his composition of Ps 137 for them to use. ${ }^{13}$

This intensification of the physical suffering of the people has to be seen in the light of another crisis - the controversies between Jews and Christians in the Middle Ages, fuelled by the Crusades, and resulting again in physical persecution. Whereas in Targum the emphasis was on the initiative of God, who would soon vindicate those in exile, the emphasis in Midrash Tehillim is more on the accountability of the people and their need to repent. A further detail in this latter Jewish meta-narrative concerns not only the self-mutilation of the Levitical singers in v. 5, but also the dreadful anger of Nebuchadnezzar, and the Levites' exemplary behaviour in response. Midrash Tehillim also universalises the vow concerning the memory of Jerusalem in v. 6: the vow made then by the Levites is now the vow of every Jew.

If a man covers his house with plaster, he must leave uncovered a small space as a mourning reminder of Jerusalem. If a man prepares all that goes with a feast, he must leave out some small thing as a reminder of Jerusalem. If a woman is adorning herself, she must leave off some small thing as a reminder of Jerusalem, for it is said If I forget thee, O Jerusalem, let my right hand forget her cunning (Ps 137:5). ${ }^{14}$

So, by identifying with the physical suffering of the first exiles the rabbis teach that those in the ongoing exile of the Diaspora must continue preserve in practical ways the memory of Jerusalem expressed in this Psalm.

\section{$6 \quad$ Psalm 137 in thirteenth century Italy}

One of the earliest Jewish illustrations of Ps 137 is also from the $13^{\text {th }}$ century. This is the Parma Psalter (c. 1280).

13 See Bar 6:4-6 and the discussion in J. Kugel, In Potiphar's House, 195-197.

14 See William G. Braude, The Midrash on Psalms: Volume 2 (New Haven, CT: Yale University Press, 1959), 81. 


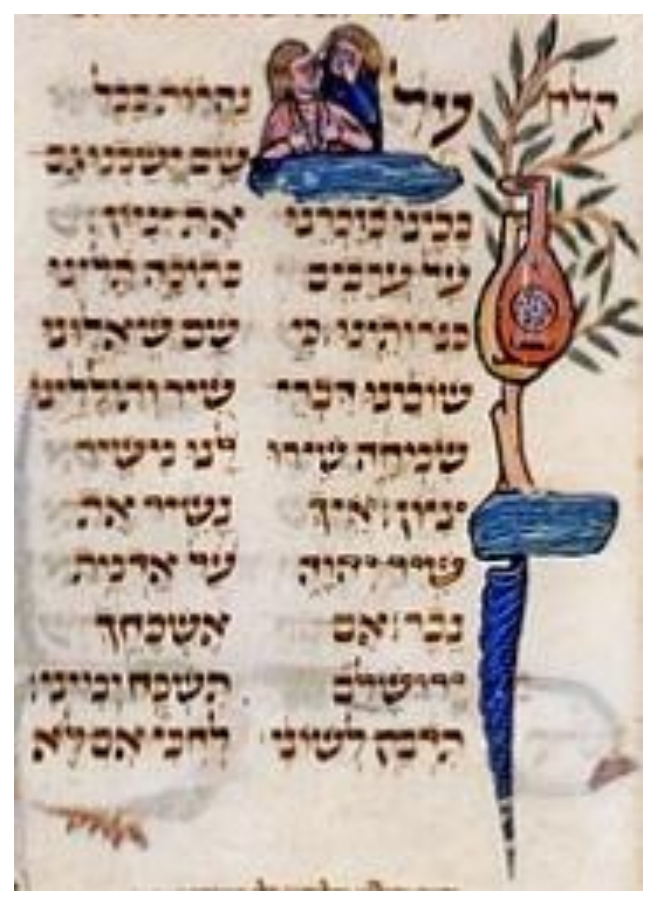

Ms. Parm. 1870 (Cod. De Rossi 510), Palatina Library, Parma, Italy. ${ }^{15}$

Given the place of the Jews in Italian society at this time, living with the consequences of the Fourth Lateran Council in 1215, with forced conversions and burning of Jewish books, the production of such a lavish manuscript marked an act of defiance against the patron's Christian persecutors. Psalm 137 is thus a highly charged psalm: we see two figures, weeping, compelled to draw the waters from the river which would eventually, according to the tradition, in Midrash Tehillim, poison them. Willow leaves frame the text, upon which are hung the lyres.

\section{$7 \quad$ Psalm 137 in the court of Mantua in sixteenth-century Italy}

One of the earliest known musical representations of Ps 137 in Jewish tradition is by Salomone Rossi, a court musician for Duke Vicenzo I in Mantua, some three hundred years after the production of the Italian Parma Psalter. Given the prohibition to sing this psalm in memory of the fallen Temple, this is particularly fascinating. By the end of the sixteenth century Italy was becoming more tolerant of Jewish culture, for the Renaissance sought to revive all aspects of the classical world, so de Rossi, still composing out of a profound concern for the future of the Jewish nation, used this new atmosphere to full advantage. He was the first Jewish musician to print Hebrew music for secular performances, taking popular tunes from the ghetto and adapting them as polyphonic psalms, in Hebrew, for synagogue liturgy. In Ps 137 the chorus is unaccompanied: Rossi still adhered to the ban on music in synagogue liturgy in memory of the destruction of the second

15 Printed with permission from the facsimile of the Parma Psalter, at www.facsimileeditions.com. 
Temple. He noted, so to speak, that harps should still be hung up on the trees. Influenced by Monteverdi and the plainchant tradition in the church of Mantua, Rossi's psalms are melismatic chants, and the only elaborations are where the voices in the psalm suggest them. Psalm 137 is full of dissonant mournful chords, sung by low and heavy voices. They begin with a chromatic progression depicting the Hebrew word "wept," and a flowing passage in unison for the Hebrew word "river." The call for revenge at the end of the psalm ("Destroy it! Destroy it!") repeatedly uses harsh, grinding chords. This is another metanarrative of Ps 137, but it is in musical form. ${ }^{16}$

\section{$8 \quad$ Psalm 137 in the twentieth century}

Returning to reception through the written word, modern Jewish commentators, writing in the light of 1948, add their own "meta-narrative" from a postHolocaust perspective. Konrad Schaefer, for example, notes that Edom serves as a symbol for the world hostile to Jerusalem. ${ }^{17}$ Schaefer reads the movement of the psalm as a drama of "unbridled emotion, from melancholy and nostalgia to rage." 18 Babylon is the personification of all that is evil: "Much of our life of faith is lived in Babylon, even as we long for Jerusalem." 19

Abraham Cohen in The Soncino Bible takes this one stage further: noting the tradition also expressed in the Talmud (Gittin 57b) which cites David the prophet as envisioning the destruction of the first Temple in v. 1 and the second Temple in v. 7 , Cohen observes that

...if we think of him [the psalmist] as an exile recently back from Babylon, viewing with horror the havoc wrought in the city he dearly loved ... Refugees from Europe, when they returned and saw how their native cities had been turned into masses of rubble by the Germans, surely shared this mood. ${ }^{20}$

The commentary on the Psalter by Avrohom C. Feuer focuses on the way that the continual memory of Jerusalem's destruction needs preserving, especially in family rituals. He quotes the importance of the recitation of Ps 137:6 at weddings by the bridegroom, who, with symbolic ashes on his head to represent the devastated Jerusalem, remembers "Jerusalem, my highest joy" as he awaits another joy - his bride. He also notes the importance of this verse as part of a grace after meals - symbolising that when the body is full, the heart must still grieve. In these ways the tragedy of Jerusalem's destruction - whether

16 For a performance of this psalm, see http://www.youtube.com/watch?v=0Xcj QLW1a98.

17 See Konrad Schaefer, Psalms (BO; Collegeville, MN: Liturgical, 2001), 321.

18 See Schaefer, Psalms, 322.

19 See Schaefer, Psalms, 323.

20 See Abraham Cohen, The Psalms. Hebrew Text and English Translation, With an Introduction and Commentary (SBB; New York, NY: Soncino, 1985), 447. 
in the sixth century BCE, the first century $\mathrm{CE}$, or in the nineteenth and twentieth centuries - becomes a perpetual motivation towards repentance and prayer for protection. $^{21}$

After 1948 some images of Ps 137 take on more hopeful connotations. One example is by Marc Chagall in the Chagall State Hall of the Knesset. On the north side, set amidst his wall tapestries which have themes of both diaspora and return, and amidst the floor mosaics which represent the love of Jewish tradition and of the land, is a large wall mosaic, six metres high and five and a half metres wide, which is of the first and fifth verses of Ps 137. The setting here is of prayers at the Western Wall (still under Jordanian control in 1966), with the Old City and Tower of David in the background.

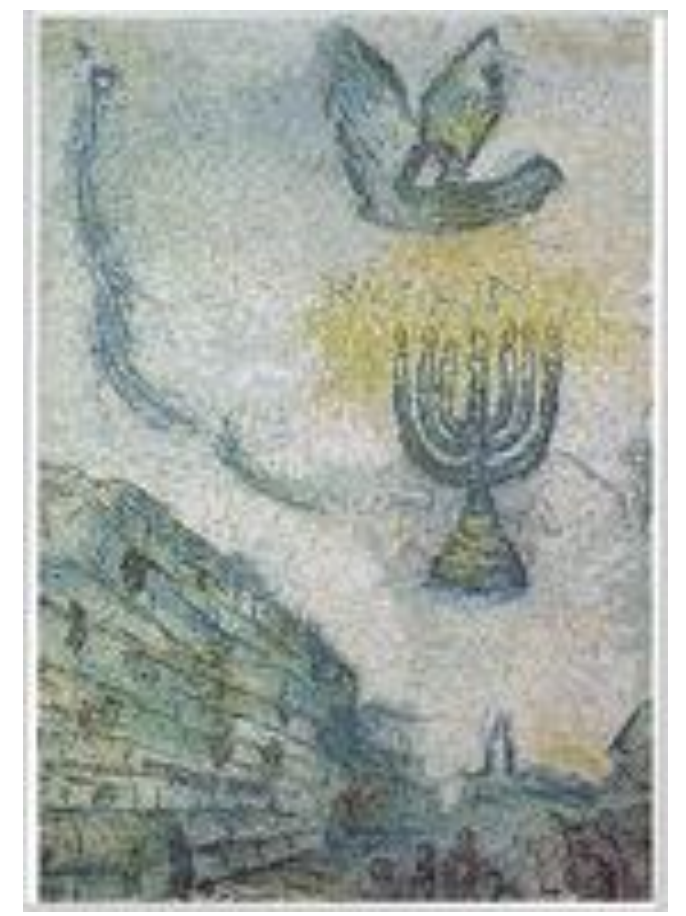

"By the waters of Babylon we sit down and weep ..."22

Instead of harps we see a Menorah, and above, echoing the angelic tradition expressed in the Targum and Midrash Tehillim, is an angel calling the

21 See Avrohom C. Feuer, Tehillim: A New Translation with a Commentary Anthologized from Talmudic, Midrashic, and Rabbinic Sources (5 vols. Artscroll Tanach Series; New York, NY: Mesorah, 1980), 1:1624; 2:1619 respectively.

22 The image is from Jacob Baal-Teshuva, Marc Chagall 1887-1985 (Cologne: Taschen, 1998), 240 (English version): permission granted by Chagall @ ADAGP, Paris and DACS, London, 2011. I am indebted to private correspondence with Ziva AmishaiMaisels for her advice on reproducing the image from the Knesset. Cf. also Ziva Amishai-Maisels, Tapestries and Mosaics of Marc Chagall at the Knesset (New York, NY: Tudor, 1973). 
people below to return to Zion. This is another "meta-narrative," in visual form but here there is more hope: God will protect.

So, whether in commentary, music or art, the Jewish reception of Ps 137 gives it a pronounced physical and political emphasis. Even when it is given a more theological orientation (for example by way of the references to angels in Targum and Chagall) this is still in order to reinforce the material and physical hope in the restoration of Jerusalem and the release of the Jewish people from pagan rule.

\section{CHRISTIAN APPROACHES TO SUFFERING THROUGH TEACHING SPIRITUAL LESSONS}

\section{Psalm 137 through the eyes of the Church Fathers}

Jerome begins his commentary with a preface about understanding Ps 137 in three ways - about the exile of the Jews to Babylon, about the expulsion of sinners from the church, "and about the superior exile, by which a sometimes noble company is led forth into the vale of tears." ${ }^{23}$ It is the third of these readings which is the most common in Christian reception and indeed is taken up by Bede. Individual phrases and words from particular verses are allegorised to give the psalm a spiritual meaning: the "superior exile" is about the place of Christians in an evil world, as pilgrims awaiting for their spiritual restoration in heaven.

The "waters of Babylon," for example, are rarely understood literally, as a means of identifying with the pain of the Jewish people. These are no longer physically poisonous waters, but waters of passion in danger of drowning the soul. They represent everything which is alien to God, the place of confusion in this world, where "the sinner who has fallen out of paradise and comes into the vale of tears." 24

The "harps" have several connotations, although none of them are literal. They can be seen as a metaphor of worldly pleasures and bodily desires which have to put aside; they are thus to be hung upon the tree, which is the cross. ${ }^{25}$ Origen offers a different reading: the "hanging up of harps" is about the failure

23 Translated by William L. Holladay, The Psalms through Three Thousand Years: Prayerbook of a Cloud of Witnesses (Minneapolis, MN: Fortress, 1993), from Germain Morin, ed., S Hieronymi Presbyteri Commentarioli in Psalmos (CCSL 72; Turnhout: Brepols, 1959), 165-242. Bede's identical observations are found in John M. Neale and Richard F. Littledale, A Commentary on the Psalms from Primitive and Medieval Writers, Volume IV (London: J. Masters, 1879), 296.

24 Taken from Jerome's Tractate on Ps 137, translated by Holladay, Psalms through Three Thousand Years, 173.

25 See Methodius, Symposium or the Banquet of the Ten Virgins 4.3, cited in Quintin F. Wesselschmidt, ed., Psalms 51-150 (ACCS.OT 8; Downers Grove, IL: InterVarsity, 2007), 379. 
to use our God-given skills. ${ }^{26}$ Jerome too, followed by Augustine, makes a similar point - that if we hang our instruments on "unfruitful trees" (the willow according to Jerome being a tree which always takes up moisture but bears no fruit) we leave ourselves open to "vices, to lust, to wantonness" and cannot communicate the Gospel to unbelievers. ${ }^{27}$ Augustine makes the point clearer still - the harps represent scripture, the commandments, and reflections on the world to come: they are not to be discarded upon barren trees. ${ }^{28}$

The "captors" and "tormentors" are no longer the Babylonians and nor are they their successors, the Romans; they are, according to Augustine, "the devil and all his minions, who have inflicted us with the wounds of sin." But this is for a refining process, in preparation for life in the heavenly Jerusalem. ${ }^{29}$ Jerusalem is never the city itself, nor is Zion the Temple in the city. ${ }^{30}$ Rather, it is the Holy and Heavenly City, which forms a neat antithesis to Babylon, the worldly city and place of all confusion. "Jerusalem is the height of joy where we enjoy God ... there shall no tempter assail us ... there nought will delight us but good: there all want will die, there perfect bliss will dawn on us." 31

The vow never to forget Jerusalem, reinforced by references to the "right hand," becomes another reference to eternal life, so that the sense runs "if I forget the Church of God, let eternal life forget me." 32

Whereas references to the Babylonians evoke a more general interpretation - sin, passions, confusion, the devil and all his works - "Edom" has often a more precise and sinister reference. Edom is Esau, the "false kinsman," set against Jacob, the true Israel, which is the Church. This is a particular theme in Augustine's sermons on the Psalms. Edom is primarily in the Synagogue, "the elder church which sought the life of the younger, and joined throughout ... in the persecutions which the Pagan rulers stirred up against the Christians." 33

26 "Quaecunque animae sedent in umbra et ignorantia, sciendum est eas rationem habere aterilem, suspensis organis quae activae vitae inserviunt." See Origen's discussion of Psalm 137 in the section "Exegetica in Psalmos" in Origenes Opera Omnia (Patrologiae Cursus Completus, Series Graeca Tomus XII; ed. Jean-Paul Migne; Paris: Migne, 1862), 1658.

27 Translated from Jerome's Commentary on Psalm 137 by Holladay, Psalms through Three Thousand Years, 172.

28 Taken from Robert Kirschner, "Two Responses to Epochal Change: Augustine and the Rabbis on Psalm 137 (136)," VC 44 (1990), 242-262 (253).

29 See Kirschner, "Two Responses to Epochal Change," 254.

30 Surprisingly, rarely is it the actual church on earth.

31 See https://www.ccel.org/ccel/schaff/npnf108.ii.CXXXVII.html (on v. 6).

32 See Augustine in Neale and Littledale, Commentary on the Psalms, 300.

33 See Augustine in Neale and Littledale, Commentary on the Psalms, 301. 
The "children of Babylon" are the confused thoughts that arise from the soul, and the one who subdues them does so by striking them against the firm and solid strength of reason and truth. ${ }^{34}$ They are "sins of the flesh born of a wretched mother (Babylon)" who have to be prevented from reaching adulthood where they will grow all the stronger and will attack us and even take us over; so in infancy they have to dashed either against the Rock which is the Word of God, or the Rock which is Christ himself. ${ }^{35}$

Perhaps surprisingly, the political vacuum left by the sack of Rome in 410 still results in reading Ps 137 in a spiritual way. Augustine, for example, preached on Ps 137 on 31 December 412, in Carthage, to assure the North African churches of the eternal nature of the "city of God" in a time of political turmoil. De civitate Dei was written shortly after this time. ${ }^{36}$ Rome, a "descendant" of Babylon, was, like Babel, transitory and destined for destruction; Jerusalem by contrast was always the "heavenly city", transcending worldly cares. As Augustine said of vv. 8-9 in Ps 137: "sigh for the everlasting Jerusalem ... Christ is now our Head; now he ruleth for us from above; in that city he will fold us to himself." 37 The challenge to the church was to escape its own "Babylonian captivity."

\section{$2 \quad$ Psalm 137 through the eyes of the sixteenth century Reformers}

By the time of the Reformation, Ps 137 was used not only for spiritual instruction; it had a physical application as well. For example, Martin Luther, once an Augustinian monk, adapted the phrase "the Babylonian Captivity of the Church" some eleven centuries after Augustine. Whereas for Augustine Babylonian hostility had meant confusion and chaos exemplified by the Empire of Rome, for Luther it meant, quite simply, the Church of Rome. Luther's second treatise of 1520 against the church's teaching on the seven sacraments, which bears the influence of Augustine's The City of God, refers to Ps 137 on two occasions. He notes how the Roman Church was like Babylon, creating oppression and confusion, whilst the origin and destiny of the true Church is the heavenly city, Jerusalem. In the section on the "Sacrament of Penance," Luther cites Ps 137:1-2, adding: "The Lord curse the barren willows of those streams!" as he highlighted the barren inefficacy of the sacraments of the Roman

34 Origen, Against Celsus 7.22, quoted in Wesselschmidt, Psalms 51-150, 379. Or again, Augustine: "What are the little ones of Babylon? Evil desires at birth ... When lust is born, before evil habit giveth it strength against thee, when lust is little, by no means let it gain the strength of evil habit; when it is little, dash it ... "Dash it against the Rock, and that Rock is Christ" (1 Cor. 10:4)." See https://www.ccel.org /ccel/schaff/npnf108.ii.CXXXVII.html (on v. 9).

35 The text commonly quoted here is 1 Cor 10:4.

36 The sermon was apparently preached on 31 December 412, see Kirschner, "Two Responses to Epochal Change," 242-243.

37 See https://www.ccel.org/ccel/schaff/npnf108.ii.CXXXVII.html. 
(Babylonian) church. And on the "Sacrament of Marriage," Luther concludes: "Herewith I hang up my harp, until another and a better man shall take up this matter with me" (Ps 137:2). ${ }^{38}$

It is not difficult to see how this metaphor of the "Babylonian Captivity of the Church" became a watchword in the later Reformation period, actually applied by all types of disenfranchised Christian groups, Catholic and Protestant, with Ps 137 now depicting the pain of physical as well as spiritual exile. This psalm has in fact been called "the quintessential psalm of the Renaissance and the Reformation." ${ }^{39}$ For example, Miles Coverdale and William Whittingham were Protestants when England was officially Catholic; Richard Crashaw was a Catholic when England was officially Protestant. All three spent time in exile on the Continent, and all three made metrical paraphrases and commentaries on this psalm. ${ }^{40}$ Coverdale's translation (still in the Anglican Book of Common Prayer), made in the 1530s, was a speedy production of an English Psalter which would suit both Archbishop and King, done with the knowledge that the threat of exile was never far away. So Coverdale paraphrased with some feeling: "How shall we synge the Lordes songe in a straunge lande?" William Whittingham, by contrast, composed his version of Ps 137 whilst in exile in Geneva during Queen Mary's reign. The reference to the "king" in v. 4 scarcely disguises the political reference: the problem for Whittingham is no longer the impossibility of a "Song of Zion" in a strange land, but rather under a strange queen:

Alas (sayd we) who can once frame,

His sorrowfull hart to syng:

The prayers of our loving God,

Thus under a straunge kyng? ${ }^{41}$

Richard Crashaw, exiled first to France and then to Italy in the mid seventeenth century, plays on the interplay between music and memory:

Ah thee Jerusalem! ah sooner may

This hand forget the mastery

38 Taken from the section "The Babylonian Captivity of the Church," in Martin Luther, Three Treatises (trans. Albert T. W. Steinhäuser, Frederick C. Ahrens and Abdel Ross Wentz; Philadelphia, PA: Fortress, 1970), 209.

39 See Hannibal Hamlin, "Psalm Culture in the English Renaissance: Readings of Psalm 137 by Shakespeare, Spenser, Milton and Others," $R Q 55$ (2002), 224-257; readapted as "Psalm 137: singing the Lord's song in a strange land" in Hannibal Hamlin, Psalm Culture and Early Modern English Literature (Cambridge: Cambridge University Press, 2004), 218-252.

40 See Hamlin, "Psalm Culture in the English Renaissance," 241-243.

41 Quoted in Hamlin, "Psalm Culture in the English Renaissance," 244, from William Whittingham, The Whole Booke of Psalmes (London: Companie of Stationers, 1562). 
Of Musicks dainty touch, then I

The Musicke of thy memory. ${ }^{42}$

\section{$3 \quad$ Psalm 137 in eighteenth century America}

Psalm 137 was used in this way by Christians well into the sixteenth and seventeenth centuries. One obvious example is Isaac Watt's Psalms of David Imitated in the Language of the New Testament (1719). Replete with contemporary British comment, it was edited and given American colouring in the late eighteenth century in New England Congregationalist Churches. ${ }^{43}$ Timothy Dwight, grandson of Jonathan Edwards (of "The Great Awakening") produced two settings of Ps 137: one was a political version which speaks of the Church's captivity not in Babylon, nor indeed in England, but in America:

Lord, in these dark and dismal days,

We mourn the hiding of thy face;

Proud enemies our path surround,

To level Zion with the ground.

Her songs, her worship, they deride,

And hiss thy word with tongues of pride,

And cry, t'insult our humble prayer,

"Where is your God, ye Christians, where?"

The political rhetoric of William Billings was more specific. The enemy "Babel" again has a literal resonance: this time it is the British forces during the American Revolution in 1776. This metrical paraphrase was written during the British occupation of Boston:

By the waters of Watertown we sat down and wept

When we remember thee, O Boston...

For they that held them in bondage requir'd of them to take up arms against their brethren.

Forbid it, Lord. God forbid!

Forbid it Lord, God forbid!

that those who have sucked Bostonian Breasts

should thirst for American Blood!...

And the version has survived; although the allusions are now more eirenical, the "Billings Round" is apparently still sung in Free Churches in the Deep South today, as noted in the round popularised by Tom Paxton.

42 Quoted in Hamlin, "Psalm Culture in the English Renaissance," from Richard Crashaw, The Poems English Latin and Greek of Richard Crashaw, (ed. L. C. Martin; Oxford: Clarendon, 1927).

43 This and the following extract are from Rochelle A. Stackhouse, The Language of the Psalms in Worship: American Revisions of Watt's Psalter (Drew University Studies in Liturgy 4; London: Scarecrow, 1997), 43-70. 


\section{$4 \quad$ Psalm 137 in the twentieth century}

A clear material and political reading is found in the Rastafarians' use of Ps 137. From their origins as a sect in Jamaica in the 1930s, the Rastafarians have always combined their belief in black liberation with a literal and Messianic use of the Hebrew Bible, especially the Psalms. "Yah" of the psalms is the name of their God, Jah Rastafari, who spoke through their Messianic leader, Emperor Haile Selassie I. The psalms, particularly those which plead the plight of the poor and oppressed, when set to reggae rhythm, become the agent of social change. Psalm 137 is crucial in this respect. So in the 1950s "Babel" refers to those from the west who sold the people of African ancestry into slavery in the Americas; the "exiles" are the harassed black Jamaican masses. Rastas reverse the genre of the psalm: the Hebrew lament becomes a protest song, not wallowing in self-pity, but defiantly "chanting down" in reggae rhythms "Babylon's" might: the actual act of singing is that which has the potential to effect social change. The "jihad" at the end of the psalm, against Babylonian domination, becomes the revolutionary call for liberation and justice:

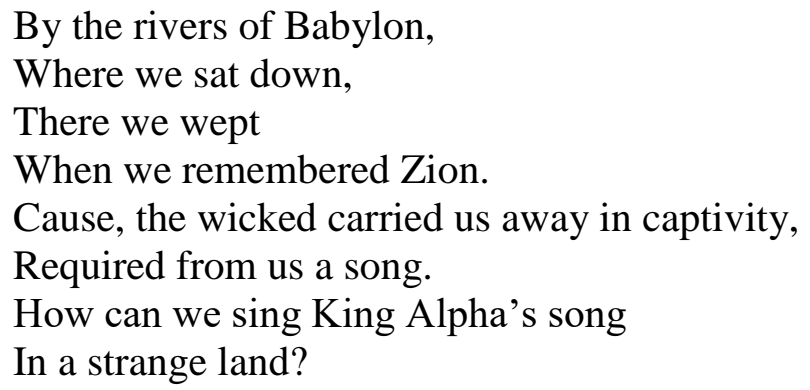

Many musicians have adapted this version of Ps 137. It was popularized by the Melodians in 1969, and again in 1975 by the reggae star Bob Marley, with Bonney Em. The Jewish protest singer Matisyahu, who combines Jewish ideas with reggae, rock and hip-hop, produced a version called "Jerusalem" in 2006. Sinead O'Connor did a quieter and more plaintive version on her album "Theology" in $2007 .{ }^{44}$

Psalm 137 is used this way in art as well. For example, Arthur Wragg created a raw and powerful black and white cartoon-like image of Ps 137 during the time of the Depression in the 1930s. Wragg actually applied the psalms to our physical condition - whether in times of poverty, unemployment, prison reform or the threat of war. His image of Ps 137 is of two tenement block windows. The top one has a withered plant on the sill and a birdcage with a hazy image of a bird inside. The bottom window is closest to us: we can see through the curtains into the blackened room. A second birdcage hangs there: this time the white upright silhouette of the bird is clear to see, but what is less clear is whether, being caged, it is unable to sing, or whether it is attempting some

44 An entry of "By the Waters" on "You Tube" will bring up most of these versions. 
choked warbling. The overall impression seems to be silence. The caption under it is simply "How shall we sing the Lord's song in a strange land?"

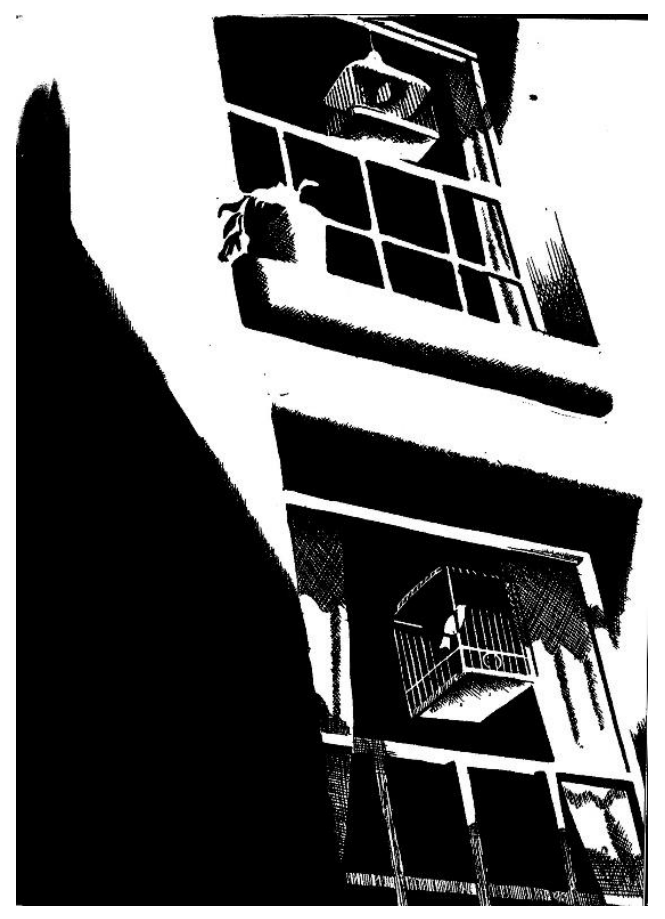

"How shall we sing the Lord's song in a strange land?" 45

The second illustration is by a contemporary Oxford artist, Roger Wagner. In a Strange Land is a series of poems and engravings, many of which are of the then deserted docklands of East London. The colours of blue, black and beige and the sense of utter barrenness with the empty cranes, piers, wharves, ladders and warehouses criss-crossing our view echo the confusion and Babel-like desolation, which is as much spiritual as it is physical. Psalm 137 is interspersed through these scenes: a most moving one is of Canning Town.

45 Taken from Arthur Wragg, The Psalms in Modern Life (London: Selwyn and Blount, 1933), no page numbers. 
460 Gillingham, “Approaches to Suffering," OTE 32/2 (2019): 444-463

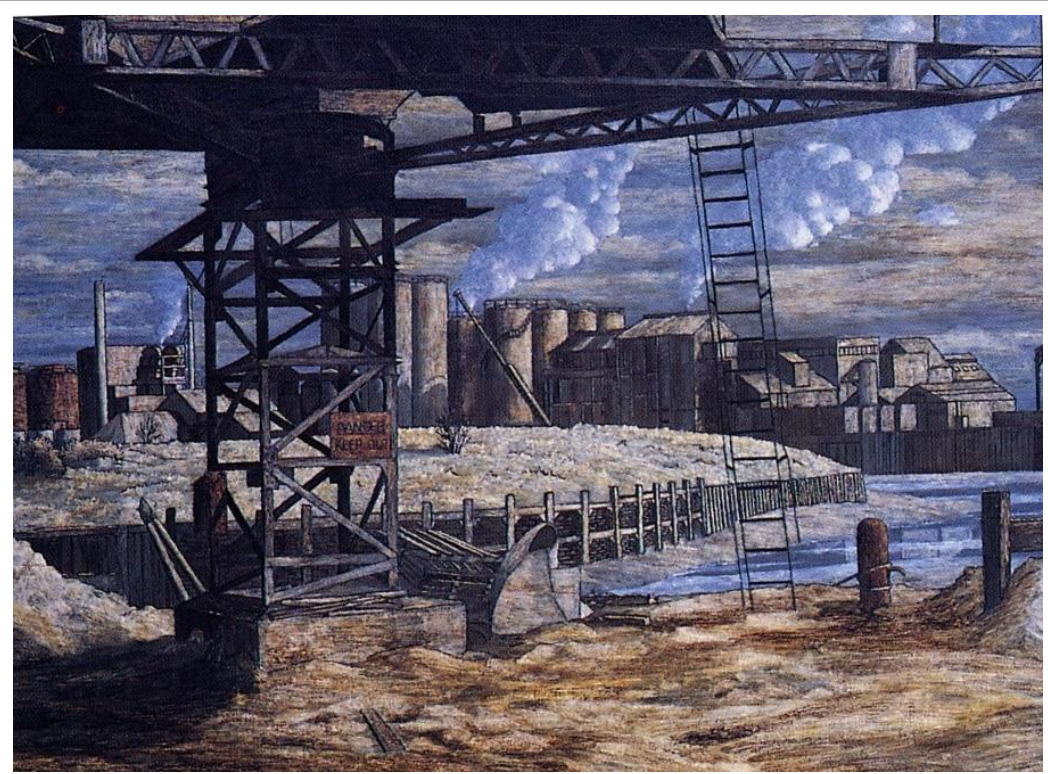

Roger Wagner “Canning Town”, 1988.

Collection Canary Wharf Ltd. ${ }^{46}$

A third illustration is by Michael Jessing, a Northumberland painter whose depiction of Ps 137 relates to his experience of living in New York City as a child, when he felt detached from nature and his spiritual self. The Babylonian figures represent statues set up before the city; the river is the Hudson; the harp, the hope of playing again - and of painting again - dreams and hopes. 


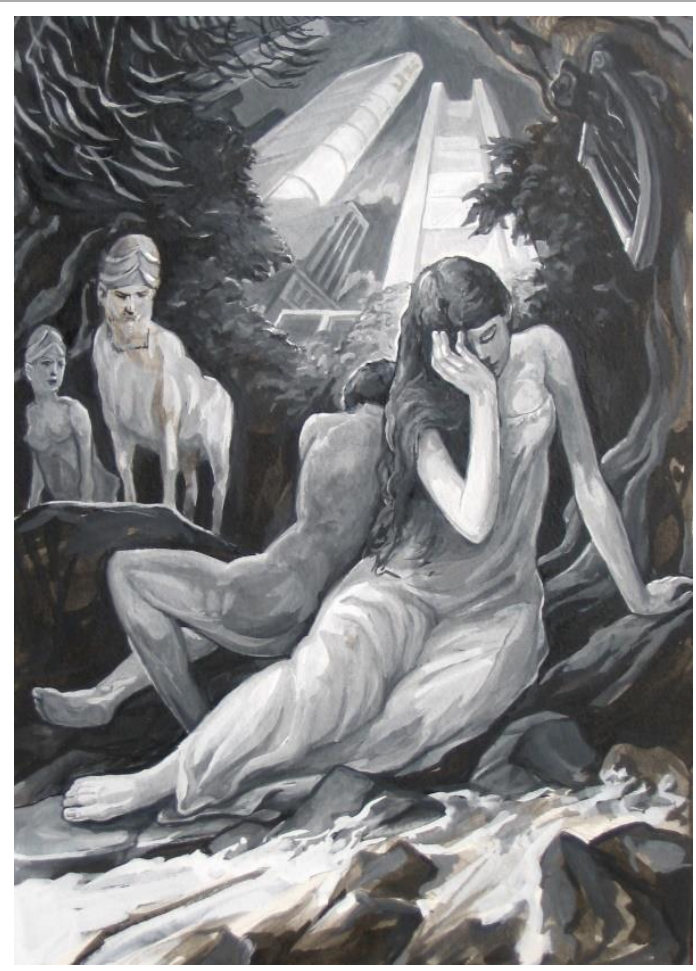

Michael Jessing: Psalm 137. ${ }^{47}$

\section{CONCLUSION: JEWISH AND CHRISTIAN RECEPTION OF PSALM 137}

This selective survey (omitting many Medieval illuminated manuscripts as well as more recent examples from Christian commentaries which both draw more on the spiritual application of this psalm) suggests that, whether in commentary, music, literary imitation or art, the Christian reception of Ps 137 in times of suffering is distinct from the Jewish one. Whereas early Jewish readings had a more corporate and physical emphasis, as crisis after crisis threatened the identity of the Jews as a people, early Christian readings are more personal and spiritualised, heightened through the use of allegory. However, in later Christian reception, from the Reformation period onwards, we find an increasing emphasis on the literal and physical relevance of this psalm; conversely, after the middle of the last century, a more personal and spiritual emphasis becomes apparent in Jewish readings of this psalm.

Reception History offers new insights into the way Ps 137 has been understood. This is a psalm which addresses not only the first exile in Babylon but the broader human predicament of innocent suffering: and because life is volatile, and we are vulnerable God has to be pursued in order to ensure that justice is done - and seen to be done. Jews and Christians who have interpreted

47 (C) Michael Jessing (http://www.mixastudio.com/biography.php ). The description of the image is from e-mail correspondence with the artist. 
Psalm 137 to address their sufferings over the last two millennia challenge us even today to read and re-read the psalm in a new light.

\section{BIBLIOGRAPHY}

Amishai-Maisels, Ziva. Tapestries and Mosaics of Marc Chagall at the Knesset. New York: Tudor, 1973.

Ball-Teshuva, Jacob. Marc Chagall 1887-1985. Cologne: Taschen, 1998.

Becking, Bob. "Does Exile Equal Suffering? A Fresh Look at Psalm 137." Pages 183202 in Exile and Suffering. A Selection of Papers read at the $50^{\text {th }}$ Anniversary Meeting of the Old Testament Society of South Africa, Pretoria August 2007. Old Testament Studies 50. Edited by Bob Becking and Dirk Human. Leiden: Brill, 2009.

Bernstein, Moshe J. "Translation Technique in the Targum to Psalms. Two Test Cases: Psalms 2 and 137." Pages 326-345 in Society of Biblical Literature 1994 Seminar Papers: 130th Annual Meeting November 19-22, 1994, the Chicago Hilton and Towers Chicago, Il. Society of Biblical Literature Seminar Papers 33. Edited by Eugene L. Lovering. Atlanta, GA: Scholars, 1994.

Braude, William G. The Midrash on Psalms: Volume 2. New Haven, CT: Yale University Press, 1959.

Brueggemann, Walter, The Message of the Psalms. Minneapolis, MN: Augsburg, 1984.

Cassiodorus, Explanation of the Psalms, Volume III Psalms 101-150 (translated and annotated by Patrick Gerard Walsh; Ancient Christian Writers 53. New York, NY: Paulist Press, 1997.

Cohen, Abraham. The Psalms. Hebrew Text and English Translation, with an Introduction and Commentary. Soncino Books of the Bible. New York, NY: Soncino, 1985.

Crashaw, Richard. The Poems English Latin and Greek of Richard Crashaw. Edited by L. C. Martin. Oxford: Clarendon, 1927. https://doi.org/10.1093/oseo/instance. $\underline{00013738 .}$.

Edwards, Timothy. Exegesis in the Targum of Psalms: The Old, the New and the Rewritten. Gorgias Dissertations 28: Biblical Studies 1. Piscataway, NJ: Gorgias, 2007.

Feuer, Avrohom C. Tehillim: A New Translation with a Commentary Anthologized from Talmudic, Midrashic, and Rabbinic Sources 5 vols. Artscroll Tanach Series. New York, NY: Mesorah, 1980.

Gillingham, Susan E. "The Reception of Psalm 137 in Jewish and Christian Traditions." Pages 64-82 in Jewish and Christian Approaches to the Psalms. Conflict and Convergence. Edited by Susan E. Gillingham. Oxford: Oxford University Press, 2013.

Gillingham, Susan E. Psalms through the Centuries: A Reception History Commentary on Psalms 1-72. Volume Two. Blackwell Bible Commentaries. Edited by John A. Sawyer, Judith Kovacs, Christopher Rowland and David M. Gunn. Oxford: Wiley-Blackwell Publishing, 2018. https://doi.org/10.1002/9781118832196.

Goldingay, John. "The Dynamic Cycle of Praise and Prayer in the Psalms." Journal for the Study of the Old Testament 20 (1981): 85-90.

Hamlin, Hannibal, Psalm Culture and Early Modern English Literature. Cambridge: Cambridge University Press, 2004). 
Hamlin, Hannibal. "Psalm Culture in the English Renaissance: Readings of Psalm 137 by Shakespeare, Spenser, Milton and Others." Renaissance Quarterly 55 (2002): 224-257. https://doi.org/10.2307/1512536.

Holladay, William L. The Psalms through Three Thousand Years: Prayerbook of a Cloud of Witnesses. Minneapolis, MN: Fortress, 1993.

Kirschner, Robert. "Two Responses to Epochal Change: Augustine and the Rabbis on Psalm 137 (136).” Vigiliae Christianae 44 (1990): 242-62. https://doi.org/10. 2307/1583697.

Kuczynski, Michael P. Prophetic Song: The Psalms as Moral Discourse in Late Medieval England. Philadelphia, PA: University of Pennsylvania Press, 1995. https://doi.org/10.9783/9781512803310.

Kugel, James. In Potiphar's House. The Interpretive Life of Biblical Times. Cambridge, MA: Harvard University Press, 1990.

Luther, Martin, Three Treatises. Translated by Albert T. W. Steinhäuser, Frederick C. Ahrens and Abdel Ross Wentz. Philadelphia, PA: Fortress, 1970.

Migne, Jean-Paul, ed. Origenes Opera Omnia. Patrologiae Cursus Completus, Series Graeca Tomus XII. Paris: Migne, 1862.

Morin, Germain, ed. S Hieronymi Presbyteri Commentarioli in Psalmos. Corpus Christianorum: Series Latina 72. Turnhout: Brepols, 1959.

Neale, John M. and Richard F. Littledale. A Commentary on the Psalms from Primitive and Medieval Writers, Volume IV. London: J. Masters, 1879.

Schaefer, Konrad. Psalms. Berit Olam: Studies in Hebrew Narrative and Poetry. Collegeville, MN: Liturgical, 2001.

Stackhouse, Rochelle A. The Language of the Psalms in Worship: American Revisions of Watt's Psalter. Drew University Studies in Liturgy 4. London: Scarecrow, 1997.

Stec, David. The Targum of Psalms. The Aramaic Bible 16. Collegeville, MN: Liturgical, 2005.

Wagner, Roger, Songs from a Strange Land. Oxford: Besalel Press, 1988.

Wesselschmidt, Quintin F., ed. Psalms 51-150. Ancient Christian Commentary on Scripture, Old Testament 8. Downers Grove, IL: InterVarsity, 2007.

Wragg, Arthur. The Psalms in Modern Life. London: Selwyn and Blount, 1933.

\section{WEBSITES (ALL ACCESSED 29 NOVEMBER 2018)}

$\underline{\text { www.facsimile-editions.com }}$

http://www.youtube.com/watch?v=0XcjQLW1a98

https://www.ccel.org/ccel/schaff/npnf108.ii.CXXXVII.html

www.rogerwagner.co.uk

http://www.mixastudio.com/biography.php

Prof Susan Gillingham, Professor of the Hebrew Bible, Tutor in Theology, Worcester College, University of Oxford, Oxford. Email susan.gillingham@ theology.ox.ac.uk. 